\title{
When Chen Meets Chan
}

\author{
Chen Chen \\ University of Alberta \\ cchen3@ualberta.ca
}

His last name is Chan. ${ }^{1}$

His last name is Chen. ${ }^{2}$

Chan is Canadian, a Chinese-Canadian.

Chen is Chinese, a Chinese living in Canada.

Chan was born here,

Shortly after that summer of Oka.

Chen arrived much later,

At a time of "Truth and Reconciliation".

Chan, a son of Hong Kong immigrants who aspired for better life.

Chen, a son of mainland Chinese family who let their child go to pursue a better life.

Chan loved sports,

He became a world-renowned figure skating star, a Canadian hero.

Chen loved sports too,

He studied sports in a world-class Canadian university, a family hero.

Chan, a model minority. ${ }^{3}$

Chen, on the trajectory of becoming a model minority.

Chan, proud of his Chinese-Canadian heritage,

Better be grateful in the eyes of Skate Canada. ${ }^{4}$

Chen, a settler of color before he knew what it meant to be one,

Better be grateful in the eyes of Immigration Canada.

Chen was excited but confused,

When he first saw Chan on television a decade ago,

A Chinese-looking young man of similar age,

Who happened to share the same last name, donning Maple Leaf,

Competing on the highest stage of sport,

On the unceded land of the Coast Salish people.

Chen hope that one day, they can meet and sit together.

When that day comes, they can exchange answers to the questions:

Cultural and Pedagogical Inquiry, Fall 2020, 12(2), pp. 40-41

ISSN 1916-3460 @ 2020 University of Alberta

http://ejournals.library.ualberta.ca/index.php/cpi/index 
Do you know, that Chen is actually Chan, that Chan is actually Chen?

Why is our last name “陳” spelled differently in foreign languages?

What is in common between us besides our last name?

If there is a homeland for you outside "Canada", Have you been missing it?

If everything goes well, they may move forward to the past:

What is it that has foregrounded our very different yet connected paths of life?

The Age of Imperialism?

150 years of British colonialism in Hong Kong?

More than 150 years of colonialization in "Canada"?

The 15,000 Canadian Pacific Railway Workers?

The Chinese Head Tax?

The Chinese Exclusion Act?

At last, they may open their hearts more, on the inevitable challenges of their lives:

As a figure-skater, to maintain artistic expression while conforming to the technicality of organized sports?

As a scholar, to maintain the ethics of accountability while conforming to the technicality of the academic-industrial complex?

As a second-generation Chinese-Canadian, or as a settler of color?

To struggle to win recognition as a model minority and to resist the complicity in the ongoing colonial violence?

As a conscientious human being,

To strive to become an individual "world champion" of some sort,

Or live for the elimination of the conditions that cause human displacement and forced migration in the first place?

\section{Endnotes:}

${ }^{1}$ Canadian former figure-skater and Olympic gold medalist Patrick Chan.

${ }^{2}$ The author.

${ }^{3}$ Coloma, R. S. (2013). 'Too Asian?' On racism, paradox and ethno-nationalism. Discourse: Studies in the Cultural Politics of Education, 34(4), 579-598.

${ }^{4}$ Chan faced backlash after an interview in which he expressed that he felt "underappreciated" in Canada. See B. Smith (2011, December 16): The truth behind Patrick Chan's China crisis. The Globe and Mail. Retrieved from: https://www.theglobeandmail.com/sports/the-truth-behind-patrick-chans-china-crisis/article4247715/

Cultural and Pedagogical Inquiry, Fall 2020, 12(2), pp. 40-41

ISSN 1916-3460 () 2020 University of Alberta

http://ejournals.library.ualberta.ca/index.php/cpi/index 